\title{
Persistent localized activity in a two-population neural-field model with spatio-temporal external input
}

\author{
Muhammad Yousaf*, Gaute T Einevoll, Tom Tetzlaff, John Wyller \\ From Twentieth Annual Computational Neuroscience Meeting: CNS*2011 \\ Stockholm, Sweden. 23-28 July 2011
}

Persistent localized activity in neural networks has been suggested to serve as the neural substrate of short-term memory [1]. Neural-field models [2] provide a powerful tool to study the existence, uniqueness and stability of this type of activity. Bump solutions are often considered as an example of localized activity. In [3], it has been shown that a two-population neural-field model (Fig.1A) exhibits up to two coexisting bump-pair solutions in the presence of homogeneous external input (or in the absence of external input). Here, we show that the same system can generate up to four coexisting bump pairs if the external input is spatially localized.

In general, neural-field models are formulated in terms of Volterra-equation systems or systems of integro-differential equations. The dynamics of bump (pulse) solutions is often studied in a simplified framework by means of ordinary differential equations describing the time evolution of the pulse widths (Amari approach, see [4]).

It has been proven that in the absence of external input this simplified pulse-width system gives the correct prediction with respect to the linear stability of stationary solutions, with one notable exception. It is often conjectured that the Amari approach might correctly predict also nonlinear aspects of the dynamics (bifurcation analysis). Here, we show that the Amari approach fails in the presence of spatially localized external input: the criteria for linear-stability of bumps in the pulsewidth system do not coincide with those obtained for

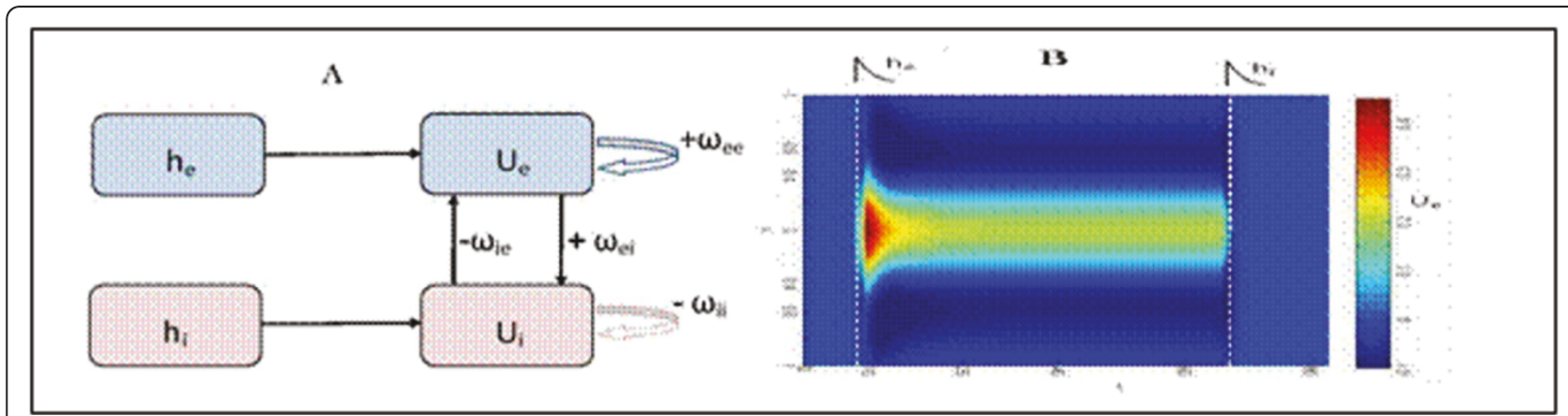

Figure 1 A. Sketch of the two population neural field model with excitatory $\left(h_{e}\right)$ and inhibitory $\left(h_{i}\right)$ external inputs. B. Persistent excitatory activity (Ue) switched on and off by a brief external input pulses. Inhibitory activity behaves in a similar way.

\footnotetext{
* Correspondence: muhay@umb.no

Department of Mathematical Sciences, Norwegian University of Life Sciences,

1432 Ås, Norway

Full list of author information is available at the end of the article
}

(c) 2011 Yousaf et al; licensee BioMed Central Ltd. This is an open access article distributed under the terms of the Creative Commons 
the full system. Therefore, for localized external input the analysis must rely on the full system.

We determine fixed-point solutions and their stability analytically and illustrate the results by means of numerical simulations. Further, we numerically show that persistent localized activity in a two-population neural-field model can be switched on and off by means of brief external-input pulses localized in space in and time (see Fig 1B).

\section{Acknowledgements}

Supported by the Research Council of Norway (eVITA [eNEURO], Notur).

Published: 18 July 2011

\section{References}

1. Wang XJ: Synaptic reverberation underlying mnemonic persistent activity. Trends Neurosci 2001, 24:455-463.

2. Wilson HR, Cowan JD: A mathematical theory of the functional dynamics of cortical and thalamic nervous tissue. Kybernetik 1973, 13:55-80.

3. Blomquist $P$, Wyller J, Einevoll GT: Localized activity patterns in two population neuronal networks. Physica D 2005, 206:180-212.

4. Amari S: Dynamics of pattern formation in lateral-inhibition type neural fields. Bio. Cybernet 1977, 27:77-87.

doi:10.1186/1471-2202-12-S1-P377

Cite this article as: Yousaf et al:: Persistent localized activity in a twopopulation neural-field model with spatio-temporal external input. BMC Neuroscience 2011 12(Suppl 1):P377.

\section{Submit your next manuscript to BioMed Central} and take full advantage of:

- Convenient online submission

- Thorough peer review

- No space constraints or color figure charges

- Immediate publication on acceptance

- Inclusion in PubMed, CAS, Scopus and Google Scholar

- Research which is freely available for redistribution

Submit your manuscript at www.biomedcentral.com/submit
C Biomed Central 